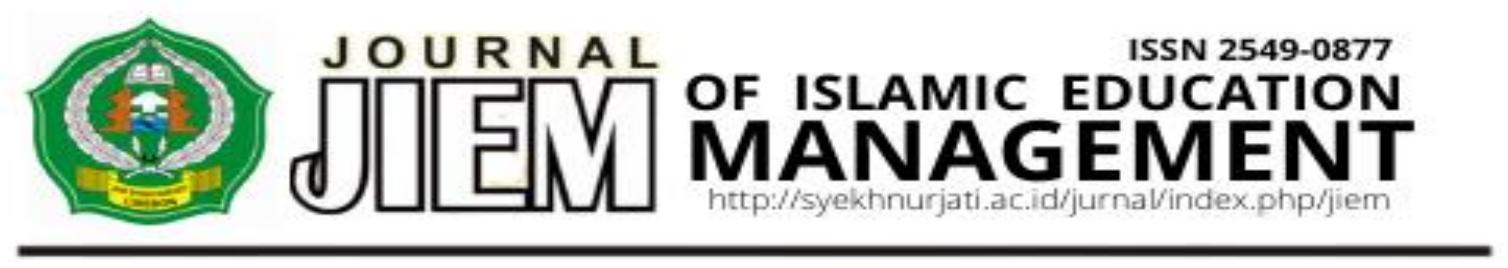

\title{
IMPROVING SCHOOL IMAGES THROUGH EDUCATION MARKETING MANAGEMENT
}

\author{
Aidah Sari, Supardi, Juhji \\ UniversitasIslam Negeri Sultan Maulana Hasanuddin Banten \\ Email: aidasari50@gmail.com, supardi@uinbanten.ac.id, juhji@uinbanten.ac.id,
}

\begin{abstract}
ABSTRAK
Penelitian ini bertujuan untuk mengetahui 1) Perencanaan pemasaran pendidikan 2) Pelaksanaan pemasaran pendidikan 3) Pengendalian pemasaran pendidikan 4) Faktor pendukung dan penghambat implementasi manajemen pemasaran pendidikan 5) solusi mengatasi hambatan implementasi manajemen pemasaran pendidikan (6) citra sekolah sebelum implementasi manajemen pemasaran pendidikan (7) peningkatan citra sekolah setelah implementasi manajemen pemasaran pendidikan. Penelitian ini menggunakan pendekatan kualitatif Studi kasus dengan teknik pengumpulan data melalui observasi, wawancara, dan studi dokumen. Instrumen penelitian yang digunakan dalam penelitian ini adalah pedoman observasi, pedoman wawancara dan dokumentasi. Analisis data melalui pengumpulan data, reduksi data, penyajian data, dan penarikan kesimpulan. Hasil penelitian ini adalah proses implementasi manajemen pemasaran pendidikan, faktor pendukung dan faktor penghambat, solusi dalam mengatasi hambatan, citra sekolah sebelum implementasi manajemen pemasaran dan citra sekolah setelah implementasi manajemen pemasaran pendidikan.
\end{abstract}

Kata kunci: Manajemen, Pemasaran pendidikan, Citra Sekolah.

\begin{abstract}
This study aims to find out 1) Educational marketing planning 2) Implementation of education marketing 3) Control of education marketing 4) Supporting and inhibiting factors in the implementation of education marketing management 5) solutions to overcome obstacles in the implementation of marketingmanagement (6) school image before the implementation of education marketing management.7)improvement of school image after the implementation of education marketing management. This research uses a qualitative case study approach with data collection techniques through observation, interviews, and document studies. The research instruments used in this study were observation guidelines, interview guidelines and documentation.Data analysis through data collection, data reduction, data presentation, and drawing conclusions. The results of this study are the process of implementing education marketing management, supporting factors and inhibiting factors, solutions to overcome obstacles, the image of the school before the implementation of marketing management and the image of the school after the implementation of education marketing management.
\end{abstract}

Keyword: Management, education marketing, school image.

PENDAHULUAN

JIEM (Journal of Islamic Education Manajemen) Vol. 4 No.1 ISSN 2549-0877 
Era persaingan global sekarang ini, telah menciptakan paradigma dunia yang tidak mengenal batas-batas territorial kedaulatan sebuah negara atau bangsa. Dampaknya turut menciptakan persaingan yang semakin tinggi pada semua aspek kehidupan masyarakat (Juhji, Khaeroni, Masto'ah, \& Habudin, 2019; Hasbullah, Juhji, \& Maksum, 2019). Begitu juga dengan pendidikan, dimana pengelolaannya tidak hanya dapat dilakukan secara tradisional akan tetapi membutuhkan kemampuan khusus sehingga output pendidikan sesuai dengan kebutuhan pangsa pasar baik nasional maupun internasional (Haryanto \& Rozza, 2013).

Persaingan dalam dunia pendidikan menjadi tidak dapat terelakkan lagi, banyak lembaga pendidikan yang ditinggalkan oleh pelanggannya sehingga dalam beberapa tahun ini banyak terjadi merger (penggabungan) dari beberapa lembaga pendidikan. Kemampuan administrator untuk memahami pemasaran pendidikan menjadi persyaratan dalam mempertahankan dan meningkatkan pertumbuhan lembaganya (Wahyudi, 2017; Juhji, 2020).

Pergeseran lingkungan dan kekuatan persaingan dalam pendidikan menyebabkan timbulnya kesenjangan antara tuntutan lingkungan dan persaingan dengan kekuatan satuan pendidikan pada berbagai jenis dan jenjang pendidikan. Situasi ini telah memaksa sebagian satuan pendidikan mengurangi atau menghentikan operasinya. Sebagai contoh, pada sejumlah lembaga pendidikan baik satuan pendidikan dasar, menengah dan satuan pendidikan lainnya. Mengalami penurunan jumlah siswanya, bahkan terpaksa ditutup dan atau dicabut ijin operasinya. Fenomena tersebut sangat meluas dan merupakan isu permasalahan yang penting untuk dikaji.

Sekolah pun selaku organisasi nirbala (Rantung, Sabijono, \& Tirayoh, 2019)perlu melakukan pemasaran, pemasaran jasa pendidikan bukan bertujuan untuk mengomersialisasikan jasa pendidikan atau mengabaikan aspek humanisme di dalam pengelolaan pendidikan. Akan tetapi, pemasaran jasa pendidikan pemasaran jasa pendidikan merupakan bentuk tanggung jawab kepada masyarakat luas terhadap jasa pendidikan yang telah, sedang, dan akan kita lakukan. Banyak sekolah yang menghadapi permasalahan pemasaran jasa pendidikan seperti membangun reputasi sekolah yang baik, mengatasi mobalisasi sumber daya pendidikan, mengembangkan program baru serta mencapai kepuasan pelanggan jasa pendiidkan siswa (Wijaya, 2016).

Pemasaran dalam konteks jasa pendidikan adalah sebuah proses sosial dan managerial untuk mendapatkan apa yang dibutuhkan dan diinginkan melaluipenciptaaan penawaran, pertukaran produk yang bernilai dengan pihak lain dalam bidang pendidikan (Khasanah, 2015; Faizin, 2017; Elytasari, 2017; Labaso, 2018; Sarifudin, \& Maya, 2019). Etika layananpemasaran dalam dunia pendidikan adalah menawarkan mutu layanan intelektual dan pembentukkan watak secara menyeluruh.Karena pendidikan bersifat lebihkompleks, yang dilaksanakan dengan penuh tanggungjawab, hasil pendidikannya mengacu jauh kedepan, membina kehidupan warga negara, generasi penerus di masa mendatang (Machali,2015).

Menurut Philip Kotler dalam Wahyudi (2017) mendefinisikan manajemen pemasaran pendidikan sebagai 
suatu proses perencanaan dan pelaksanaan pemikiran (Parid, 2016), penetapan harga, promosi serta penyaluran gagasan, barang dan jasa untuk menciptkan pertukaran yang memuaskan tujuan-tujuan individu dan organisasi.Salah satu fungsi pemasaran di sekolah/madrasah adalah untuk membentuk citra baik terhadap lembaga dan menarik sejumlah calon siswa.Dengan demikian citra merupakan salah satu faktor dalam upaya pemasaran pendidikan yang berdampak positif terhadap peningkatan minat pengguna jasa pendidikan dilembaga pendidikan tersebut. Citra yang positif merupakan aset yang sangat berharga di pasar (marketplace). "The marketing imagination is the starting point of success in marketing" (Alma, 2018).

Pemasaran bertujuan untuk memberikan arah dan tujuan padakegiatankegiatan lembaga pendidikan. Selain itu,tujuan pemasaran adalah membuat produk perusahaan atau lembaga yang kompetitif karena ada nilai perbedaan dengan kompetitor, semakin kuat nilai perbedaan, semakin baik bagi perusahaan atau lembaga.Dalam menemukan perbedaan dibutuhkan kejelian, kecermatan, dan kreativitas tinggi (Munir, 2018).

Proses manajerial pemasaran dalam dunia pendidikan terdiri dari: 1) Perencanaan, perencanaan dalam pemasaran pendidikan adalah sebagai patokan dalam kegiatan pemasaran yang akan dilaksanakan agar efektif dan efisien. Dalam tahap ini harus memperhatikan halhal sebagai berikut: identifikasi pasar, Segmentasi pasar, Positioning atau diferensiasi (Muhaimin, 2010). Beberapa hal yang perlu dilakukan dalam membuat perencanaan pemasaran adalah: a) Menentukan visi, misi, tujuan umum, dan tujuan khusus lembaga pendidikan (Supardi, 2017); b) Menganalisis ancaman dan peluang eksternal lembaga pendidikan; dan c) Mengetahui kecenderungan "kondisi pasar" sekaligus menentukan calon siswa yang akan dipilih lembaga pendidikan (Hidayat \& Wijaya, 2017);2) pelaksanaan, dalam pelaksanaan pemasaran disekolah satu hal penting yang perlu diperhatikan dalam pelaksanaan pemasaran adalah memperhatikan variabel-variabel yang dapat menarik minat pelanggan; dan 3) pengawasan, merupakan upaya untuk mengamati secara sistematis dan berkesinambungan, merekam, memberikan penjelasan, petunjuk, pembina, dan meluruskan berbagai hal yang kurang tepat, memperbaiki kesalahan dan merupakan kunci keberhasilan dan keseluruhan proses manajemen (Tatang, 2015).

Menurut Alma (2018), citra merupakan kesan, impresi, perasaan atau konsepsi yang ada pada publik mengenai perusahaan, suatu objek, orang atau mengenai lembaga. Untuk membentuk citra baik terhadap lembaga dan dalam menarik minat sejumlah calon siswa, maka lembaga pendidikan telah menggunakan berbagai upaya strategi yang dikenal dengan strategi bauran pemasaran (strategi marketing mix). Dalam elemen bauran pemasaran yang terdiri atas $7 \mathrm{P}$ yaitu Promotion, Place, Price, Product, Physical evidence, People dan Process (Wijaya, 2016).Dengandemikian, citra adalah kesan yang diperoleh sesuai dengan pengetahuan pemahaman seseorang tentang sesuatu. Citra terbentuk dari bagaimana suatu lembaga pendidikan melakukan kegiatan operasionalnya, yang mempunyai landasan utama ada segi layanan. Citra yang baik dari suatu lembaga akan mempunyai 
dampak yang menguntungkan, sedangkan citra yang jelek akan merugikan,

Jika demikian, maka kepentingan untuk membangun citra sangatlah penting, sementara pendekatan terbaik dalam membangun citra adalah lewat pemasaran, seperti halnya kita melihat banyak sekolah bagus di negeri ini akan tetapi mereka gagal membangun citranya sehingga tidak mendapat kepercayaan masyarakat. Sebaliknya sekolah-sekolah yang saat ini berkibar kebanyakan adalah sekolahsekolah yang mampu memberikan positioning bagi masayarakat walaupun tidak menjadi jaminan bahwa itu merupakan sekolah yang bermutu.

Berdasarkan latar belakang dan kajian literatur diatas maka dapat dirumuskan masalahnya sebagai berikut: 1) Bagaimana perencanaan pemasaran pendidikan di SMP Negeri 1 Pontang, 2) Bagaimana pelaksanaan pemasaran pendidikan di SMP Negeri 1 Pontang, 3) Bagaimana pengendalian/pengawasan pemasaran pendidikan di SMP Negeri 1 Pontang, 4) Bagaimana faktor pendukung dan penghambat implementasi manajemen pemasaran pendidikan di SMP Negeri 1 Pontang, 5) Bagaimana solusi mengatasi hambatan implementasi manajemen pemasaran pendidikan di SMP Negeri 1 Pontang, 6) Bagaimana citra sekolah sebelum implementasi manajemen pemasaran pendidikan di SMP Negeri 1 Pontang, 7) Bagaimana peningkatan citra sekolah setelah implementasi manajemen pemasaran pendidikan di SMP Negeri 1 Pontang.

Dari perumusan masalah tersebut maka tujuan penulisan penelitian ini untuk mengetahui 1) Perencanaan pemasaran pendidikan 2) Pelaksanaan pemasaran pendidikan 3) Pengendalian pemasaran pendidikan 4) Faktor pendukung dan penghambat implementasi manajemen pemasaran pendidikan 5) solusi mengatasi hambatan implementasi manajemen pemasaran pendidikan (6) citra sekolah sebelum implementasi manajemen pemasaran pendidikan (7) peningkatan citra sekolah setelah implementasi manajemen pemasaran pendidikan.

\section{METODE}

Metode penelitian yang digunakan adalah metode penelitian deskriptif kualitatif dengan desain penelitian studi kasus yang dimaksudkan untuk menggali informasi dan memberi gambaran, mengemukakan atau menguraikan berbagai data atauteori yang telahada (Supardi, 2017). Lokasi yang digunakan sebagai tempat penelitian adalah di SMP Negeri 1 Pontang Jl. Ciptayasa Km.12 Pontang, KubangPuji, Kec. PontangKab.Serang-Banten.

Peneliti berperan sebagai pengamat partisipatif dan pewawancara mendalam. Teknikpengumpulan data yang digunakan adalah observasi, wawancara, dokumentasi, dan catatan lapangan. Terdapat dua sumber data dalam penelitian ini yaitu 1) Data primer, yaitu kepala sekolah, wakil kepala sekolah, waka kesiswaan dan dewan guru SMP Negeri 1 Pontang, (2) Data Sekunder, dalam penelitian ini data sekunder diperoleh dari: (a) Sumber tertulis dari penelitian ini nantinya didapatkan dari, penelitian terdahulu, jadwal pelaksanaan pemasaran pendidikan, hasil pelaksanaan kegiatan pemasaran pendidikan, arsip dan dokumen lain yang dapat menunjang penelitian ini .(b) Foto dalam penelitian penggunaan foto-foto sebagai pelengkap dari data yang telah diperoleh melalui observasi atau pengamatan, dan wawancara. Analisis data 
melalui pengumpulan data, reduksi data, penyajian data dan penarikan kesimpulan.

\section{HASIL DAN PEMBAHASAN}

Telah diketahui bersama teori tentang manajemen pemasaran pendidikan bahwa proses manajerial pemasaran dalam dunia pendidikan terdiri dari perencanaan, pelaksanaan dan pengendalian/pengawasan. Maka dari itu peneliti bermaksud menggambarkan dan mendeskripsikan bagaimana proses implementasi manajemen pemasaran pendidikan melalui tiga fungsi perencanaan, pelaksanaan dan pengawasan dalam penelitian implementasi manajemen pemasaran pendidikan dalam meningkatakan citra sekolah di SMP Negeri 1 Pontang.

\section{Perencanaan Pemasaran Pendidikan}

Perencanaan pemasaran pendidikan di SMP Negeri 1 Pontang dilakukan dengan merumuskan rencana pemasaran yang dilaksanakan melalui rapat bersama para panitia pelaksana pemasaran pendidikan dibawah tanggung jawab kepala sekolah dan diketuai oleh waka kesiswaan, hal ini dimaksudkan agar perencanaan pemasaran pendidikan yang dilaksanakan akan dapat tersusun lebih efektif untuk mencari cara yang tepat dalam memperkenalkan program-program unggulan yang dimiliki SMP Negeri 1 Pontang kepada konsumen pendidikan baik sekolah-sekolah dasar dan masyarakat.

SMP Negeri 1 Pontang telah melakukan perencanaan dengan baik hal ini dapat dilihat adanya penyusunan rencana pemasaran meliputi: 1)Pembentukan struktur organisasi pemasaran pendidikan, sebagai proses membagi kerja ke dalam tugas-tugas yang lebih kecil, membebankan tugas-tugas itu kepada orang yang sesuai dengan kemampuannya dan mengalokasikan sumber daya, serta mengkoordinasikannya dalam rangka efektivitas pencapaian tujuan pemasaran pendidikan.

Pengorganisasian sekolah dibentuk agar pembagian tugas dan tanggung jawab lebih jelas sehingga guru ataupun staf yang di libatkan mempunyai tanggung jawab dan kewajiban dalam proses pelaksanan pemasaran pendidikan. 2) Rencana waktu/tanggal pelaksanaan pemasaran pendidikan. 3) Rencana daerah pemasaran, dengan cara melakukan identifikasi pasar yaitu dengan menganalisis untuk mengetahui kondisi masayarakat sasaran dan menggali data tentang hal-hal yang dibutuhkan dan diinginkan oleh pengguna jasa pendidikan, dengan demikian dapat direncanakan tentang bagaimana cara strategi pemasaran pendidikan yang akan digunakan. 4) Segmentasi dan positioning, pada dasarnya setiap lembaga pendidikan mempunyai pangsa pasar tersendiri, SMP Negeri 1 Pontang pangsa pasar atau target daerah pemasaran pendidikannya adalah sekolah-sekolah Dasar negeri/swasta di sekitar SMP Negeri 1 Pontang dan merupakan zonasi dari sekolah, dalam melakukan positioning SMP Negeri 1 Pontang melakukan cara yang bervariasi yaitu mengadakan kegiatan di sekolah dengan mengundang masyarakat dan wali murid untuk hadir ke sekolah seperti mengadakan acara open house, pameran/pentas seni, selalu ikut serta dan berpartisipasi aktif dalam kegiatankegiatan perlombaan diluar sekolah agar nantinya publik atau masyarakat mengetahui prestasi dan keunggulan yang dimiliki sekolah. 5) Rencana programprogram pemasaran pendidikan, SMP Negeri 1 Pontang merencanakan program- 
program terkait dengan pemasaran pendidikan yang dirumuskan pada saat melakukan rapat bersama para panitia pemasaran pendidikan, program yang dirumuskan diantaranya akan melakukan sosialisasi dan kunjungan ke sekolahsekolah dengan memberikan brosur, serta memberikan imformasi terkait program kegiatan yang ada di sekolah salah satunya kegiatan ekstrakurikuler, selain itu juga memberikan informasi seperti adanya program pemberian beasiswa, programprogram kegiatan keagamaan dan program pembentukan karakter siswa melalui kegiatan pembiasaan.

\section{Pelaksanaan Pemasaran Pemasaran}

Pelaksanaan pemasaran pemasaran pendidikan di SMP Negeri 1 Pontang tergolong cukup efektif dan tepat guna karena telah dilaksanakan dengan beberapa cara/strategi yang berfariasi disesuaikan dengan situasi dan kondisi dengan inovasiinovasi tertentu. Menurut Syafi'ur Rahman (2015) bahwa dalam kegiatan Pelaksanaan pemasaran dapat dilakukan baik secara langsung maupun tidak langsung. SMP Negeri 1 Pontang telah melakukan pemasaran pendidikan dengan dua cara tersebut yaitu: 1) Pemasaran secara langsung, yaitu melalui promosi dan publikasi, pemanfaatan IT, brosur, banner, dan sosialisasi ke sekolah-sekolah, hal ini dilaksanakan dengan bentuk ceramah visi, misi dan tujuan SMP Negeri 1 Pontang, sambil memberikan brosur. Akan tetapi hal itu bukanlah informasi yang utama. Penekanan informasi yang disampaikan adalah pada bagaimana bentuk pelayanan pendidikan yang ada di SMP Negeri 1 Pontang yang mengutamakan mutu dan kualitas pelayanan pendidikan dengan sebaik mungkin demi kepuasan pelanggan pendidikan, di samping itu juga menyampaikan program-program unggulan yang dimiliki sekolah. 2) Pemasaran secara tidak langsung, yaitu melalui penawaran berbagai kegiatan ekstrakurikuler, program beasiswa, program-program kegiatan keagamaan, program pembentukan karakter siswa melalui kegiatan pembiasaan yang dilakukan di sekolah, melaksanakan kegiatan-kegiatan didalam sekolah dengan mengundang masyarakat umum seperti mengadakan open house, pameran/pentas seni, kegiatan perlombaan disekolah dan ikut berpartisipasi dalam kegiatan perlombaan diluar sekolah. Dengan melakukan kegiatan-kegiatan tersebut secara tidak langsung SMP Negeri 1 Pontang melakukan promosi sehingga publik mengetahui kondisi sekolah, keunggulan dan prestasi yang di miliki sekolah.

Untuk membentuk citra baik terhadap lembaga dalam menarik minat sejumlah siswa maka dalam pelaksanaan pemasaran pendidikan SMP Negeri 1 Pontang juga telah menerapkan strategi bauran pemasaran (strategi marketing mix), dalam bauran pemasaran yaitu: 1) Product (Produk), SMP Negeri 1 Pontang produk yang ditawarkan meliputi fasilitas dan pelayanan sekolah seperti menawarkan kegiatan kesenian, keagamaan, kegiatan olahraga dengan di dukung oleh fasilitasfasilitas sekolah. 2) Price (Harga), harga yang ditetapkan di SMP Negeri 1 Pontang adalah dengan membebaskan biaya (tidak dipungut biaya). 3) Place (Lokasi), lokasi SMP Negeri 1 Pontang terletak di tempat yang sangat strategis karena sangat mudah dijangkau oleh masyarakat, jalan menuju sekolah mudah diakses oleh transpotasi umum. 4) Promotion (Promosi), Promosi yang dilakukan SMP Negeri 1 Pontang melalui brosur, spanduk, media sosial, dan 
kunjungan ke sekolah. 5) People (Orang), kualifikasi akademik tenaga pendidik dan kependidikan dari 29 guru, 3 diantaranya S3, 23 lulus S1, 2 guru beriijazah D3, dan 1 guru berijazah SLTA. 6) Physical Avidence (Bukti fisik), sarana dan prasarana di SMP Negeri 1 Pontang memadai dan menunjang kegiatan proses belajar mengajar. Process (proses), didukung oleh kurikulum 2013 serta kegiatan ekstrakurikuler, kegiatan tambahan dan pembiasaan untuk siswa.

Disamping itu juga upaya yang dilakukan SMP Negeri 1 Pontang dalam meningkatakan citra sekolah adalah dengan melakukan evaluasi dan perbaikanperbaikan agar mutu sekolah semakin meningkat, perbaikan-perbaikan fasilitas sekolah demi memenuhi kepuasan pengguna jasa pendidikan, selain itu juga upaya yang dilakukan adalah dengan terus melakukan peningkatan kualitas mutu pelayanan sekolah dan membuat pelayanan yang ditawarkan lebih berfariasi seperti kegiatan olahraga, kesenian, keagamaan, kursus-kursus dan sebagainya, sehingga nantinya calon siswa dan orang tua tertarik masuk untuk sekolah di SMP Negeri 1 Pontang.

\section{Pengawasan Pemasaran Pendidikan}

Pengawasan pemasaran pendidikan yang dilakukan SMP Negeri 1 Pontang dilakukan baik secara langsung maupaun secara tidak langsung, control dilakukan oleh Kepala Sekolah sebagai penanggung jawab dan Waka Kesiswaan sebagai ketua pelaksana pemasaran pendidikan, pengawasan yang dilakukan yaitu pada saat melakukan perencanaan dan perumusan pemasaran pendidikan, pengawasan saat kerja berlangsung untuk memastikan bahwa rencana-rencana, sasaran-sasaran telah dicapai, dan pengawasan setelah kegiatan telah dilaksanakan dengan cara mengukur hasil suatu kegiatan dengan analisis hasil laporan kegiatan pelaksanaan pemasaran pendidikan yang dilaksanakan dalam bentuk pertemuan/rapat oleh kepala sekolah dengan segenap guru dan karyawan yang terlibat sebagai tim pelaksana pemasaran pendidikan yang nantinya akan di evaluasi tentang bagaimana realisasi pelaksanaan rencana kerja yang telah dirumuskan sebelumnya. Jika ditemukan kekurangan atau hambatan dapat segera dilakukan perbaikanperbaikan.

\section{Faktor Pendukung dan Faktor Penghambat Implementasi Manajemen Pemasaran Pendidikan}

Secara keseluruhan faktor pendukung implementasi manajemen pemasaran pendidikan di SMP Negeri 1 Pontang adalah kekuatan yang dimiliki sekolah baik dari internal maupun eksternal. Internal yaitu sarana dan prasarana, kualitas dan keunggulan sekolah, prestasi sekolah, pembebasan biaya sekolah, output siswa, dan letak sekolah yang strategis. Sedangkan eksternal adanya dukungan dari wali siswa dan hubungan kerja sama antar sekolah dan masyarakat.

Faktor penghambat implementasi manajemen pemasaran pendidikan di SMP Negeri 1 Pontang berasal dari internal dan eksternal, internal yaitu masih kurangnya pemahaman penyelenggara pendidikan dalam memahami pemasaran pendidikan, sedangkan eksternal adanya persaingan dengan sekolah lain yang sama-sama menawarkan jasa pendidikan. 
Solusi Mengatasi Hambatan

Implementasi Manajemen Pemasaran Pendidikan

Secara umum adanya hambatan atau kendala dalam setiap kegiatan adalah merupakan hal yang wajar, namun demi pencapaian tujuan yang telah ditetapkan maka kendala tersebut harus segera di tangani dan dicari solusi yang tepat untuk mengatasinya. Hambatan yang dihadapi pada implementasi manajemen pemasaran pendidikan di SMP Negeri 1 Pontang dan solusi dalam mengatasi hambatan pemasaran pendidikan di SMP Negeri 1 Pontang yaitu dengan mengetahui apa penyebab permasalahan yang kemudian akan dimusyawarahkan bersama melalui rapat yang diadakan oleh kepala sekolah, solusi yang dilakukan SMP Negeri 1 Pontang dalam mengatasi hambatan pemasaran pendidikan antara lain dengan meningkatkan kualitas pelayanan sekolah, peningkatan mutu, perbaikan-perbaikan fasilitas sarana dan prasarana sekolah, meningkatan kegiatan-kegiatan sekolah seperti kegiatan ekstrakurikuler dan terus meningkatankan prestasi-prestasi dan keunggulan sekolah dengan harapan mampu menarik para konsumen dan mempunyai daya saing tersendiri bagi sekolah. Selain itu juga selalu memberikan arahan-arahan kepada guru atau karyawan agar memahami pemasaran pendidikan dan tetap menjalin hubungan kerjasama yang baik dengan pihak-pihak yang dapat mendukung terhadap ketercapaian tujuan sekolah agar mampu bersaing dengan sekolah lain.

\section{Citra Sekolah Sebelum Implementasi Manajemen Pemasaran Pendidikan}

SMP Negeri 1 Pontang sebelum implementasi pemasaran pendidikan telah mendapat kepercayaan dan citra baik dari masyarakat umum akan tetapi masih ada beberapa persepsi terhadap citra SMP Negeri 1 Pontang yang masih kurang baik disebabkan kurangnya mengetahui kondisi sekolah secara objektif, kurangnya pemahaman publik terhadap sekolah, program-program apa saja yang ada di sekolah, keunggulan apa saja yang dimiliki sekolah dan hal-hal lain yang berkaitan dengan sekolah yang bisa jadi tidak diketahui oleh masyarakat umum karena kurangnya informasi yang didapatkan tentang SMP Negeri 1 Pontang. Citra yang kurang baik akan merugikan sekolah, citra yang kurang baik berarti masyarakat mempunyai kesan negatif terhadap sekolah.

Upaya-upaya yang dilakukan SMP Negeri 1 Pontang untuk mengatasi persepsi-persepsi negatif dari publik atau masyarakat umum dalam menjaga citra dan nama baik sekolah yaitu dengan lebih memfokuskan pada perbaikan yang bersifat internal, dengan cara meningkatkan kinerja para guru dan staf (SDM), dengan fokus pada perbaikan internal diharapakan mutu pendidikan yang dihasilkan oleh para pengajar akan meningkat, disamping itu juga dengan meningkatkan kedisiplinan dan tata tertib sekolah karena apabila kedisiplinan dan tata tertib terjaga dengan baik masyarakat umum akan memberikan respon positif terhadap sekolah, selain itu SMP Negeri 1 Pontang juga selalu mengikuti even perlombaan baik tingkat daerah maupun propinsi dengan harapan agar masyarakat umummengetahui prestasi-prestasi sekolah sehingga sekolah mendapat kepercayaan dari masyarakat umum. 


\section{Citra Sekolah Setelah Implementasi Manajemen Pemasaran Pendidikan}

Seperti salah satu fungsi manajemen, pemasaran bertujuan untuk memberikan arah dan tujuan pada kegiatan-kegiatan lembaga pendidikan, selain itu juga membuat produk suatu lembaga pendidikan yang kompetitif karena ada nilai perbedaan dan kompetitor, pendekatan terbaik dalam membangun citra adalah lewat pemasaran pendidikan, sehingga pemasaran lembaga pendidikan mutlak diperlukan. hal ini mendorong SMP Negeri 1 melakukan pemasaran pendidikan karena adanya persaingan antar lembaga pendidikan, hal ini terlihat dari munculnya berbagai lembaga pendidikan yang selalu menawarkan keunggulannya masing-masing, perlunya meyakinkan masyarakat dan pelanggan jasa pendidikan (siswa, orangtua siswa dan pihak terkait lainnya) bahwa sekolah yang dikelola masih memiliki eksistensi, disamping itu juga masyarakat atau pelanggan jasa pendidikan perlu mengetahui perkembangan sekolah sehingga sekolah yang dikelola dapat dikenal dan dipahami oleh masyarakat terutama pelanggan jasa pendidikan.

Citra sekolah setelah implementasi pemasaran pendidikan di SMP Negeri 1 Pontang mengalami peningkatan dibuktikan dengan kepercayaan orang tua siswa yang mendaftarkan anaknya ke SMP Negeri 1 Pontang sehingga minat pengguna jasa pendidikan setiap tahunnya rata-rata meningkat sebagaimana pada gambar berikut:

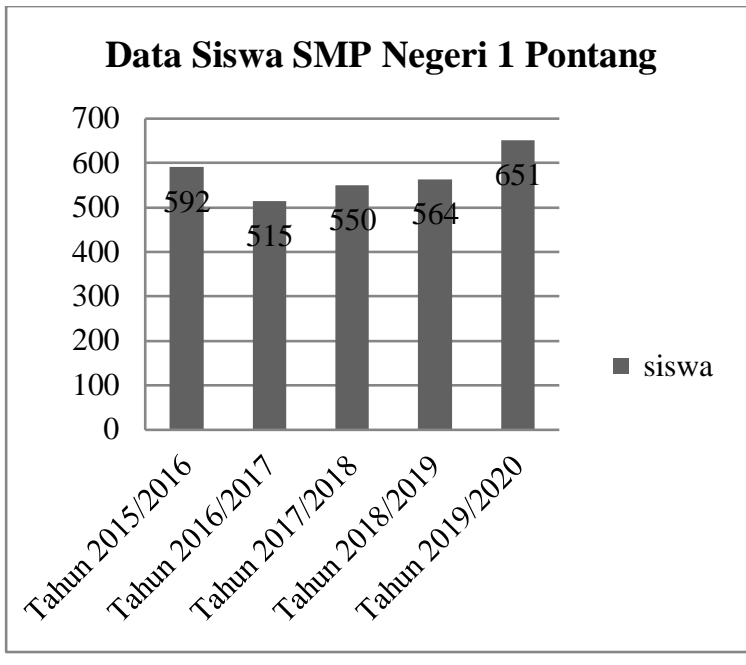

Gambar 1 Perbandingan Jumlah Siswa SMP Negeri 1 PontangTahun 2015-2020

Oleh adanya pertumbuhan jumlah siswa yang semakin meningkat pertahunnya di SMP Negeri 1 Pontang, hal itu menunjukkan bahwa kepercayaan pengguna jasa pendidikan terhadap SMP Negeri 1 Pontang semakin kuat karena citra yang baik dari sekolah akan mempunyai dampak menguntungkan, citra yang baik berarti masyarakat khususnya konsumen mempunyai kesan positif terhadap sekolah sehingga mampu menarik minat sejumlah calon siswa untuk mendaftarkan diri ke SMP Negeri 1 Pontang.

Selain meningkatnya minat pengguna jasa pendidikan dengan adanya implementasi pemasaran pendidikan kepercayaan masyarakat semakin kuat dan citra sekolah semakin meningkat, sekolah lebih dikenal lagi oleh masyarkat umum, adanya dukungan dari masyarakat dan orang tua siswa serta terjalinnya kerja sama antara orang tua siswa dengan sekolah.

\section{KESIMPULAN}

Dari hasil penelitian yang dilakukan maka penulis menyimpulkan bahwa implementasi manajemen 
pemasaran pendidikan di SMP Negeri 1 Pontang bisa dikatakan baik, pemasaran pendidikan di SMP Negeri 1 Pontang menjalankan fungsi-fungsi manajemen mulai dari perencanaan, pelaksanaan, dan pengendalian/pengawasan. Pada tahap perencanaan dimulai dengan pembentukan struktur organisasi, menentukan rencana waktu, rencana daerah pemasaran dan merencanakan program pemasaran pendidikan, Pelaksanaan pemasaran pendidikan dilakukan dengan dua cara yaitu pemasaran secara langsung (promosi publikasi, pemanfaatan IT, brosur, banner, dan sosialisasi ke sekolah-sekolah). Pemasaran secara tidak langsung (melalui penawaran berbagai kegiatan ekstrakurikuler dan program sekolah). selain itu juga strategi yang digunakan yaitu dengan menerapkan bauran pemasaran. Pengawasan pemasaran pendidikan yang dilakukan SMP Negeri 1 Pontang dilakukan oleh kepala sekolah baik secara langsung maupaun secara tidak langsung, Faktor pendukung: internal, yaitu prestasi sekolah, sarana dan prasarana, pembebasan biaya sekolah, output siswa, dan letak sekolah yang strategis. eksternal, yaitu adanya dukungan dari wali siswa dan hubungan kerja sama antar sekolah dan masyarakat. Faktor penghambat: internal yaitu masih ada beberapa penyelenggara pendidikan di SMP Negeri 1 Pontang yang kurang memahami pemasaran pendidikan, eksternal yaitu adanya persaingan dengan sekolah lain yang sama-sama menawarkan jasa pendidikan. Solusi dalam mengatasi hambatan pemasaran pendidikan antara lain dengan meningkatkan kualitas pelayanan mutu, perbaikan fasilitas, memberikan arahan kepada guru agar memahami pemasaran pendidikan dan tetap menjalin hubungan kerjasama yang dapat mendukung terhadap ketercapaian tujuan sekolah. Citra sekolah sebelum implementasi manajemen pemasaran di SMP Negeri 1 Pontang telah mendapatkan citra positif akan tetapi masih ada persepsi masyarakat terhadap citra SMP Negeri 1 Pontang yang masih kurang baik. Citra sekolah setelah implementasi manajemen pemasaran pendidikan yaitu kepercayaan masyarakat semakin kuat, sekolah lebih dikenal lagi oleh masyarkat umum, adanya dukungan dari masyarakat dan orang tua siswa serta terjalinnya kerja sama antara orang tua siswa dengan sekolah.

\section{SARAN}

Tanpa mengurangi rasa hormat kepada semua pihak dan demi suksesnya kegiatan pemasaran pendidikan, maka penulis memberikan saran sebagai berikut: Meningkatkan kemampuan guru dan karyawan untuk memahami pemasaran pendidikan, meningkatakan dan memberdayakan seluruh sumber daya yang ada untuk perbaikan dan peningkatan kualitas pendidikan sehingga mempertahakan eksistensi lembaga di tengah arus gelombang persaingan yang semakin ketat saat ini. Selalu mementingkakan kepuasan unsur pemasaran pendidikan yaitu kebutuhan, kepuasan, dan pelanggan stakeholder, dengan pemenuhan beberapa unsur tersebut maka dengan itu sekolah dapat diharapkan memetik nilai positif berupa meningkatnya peserta didik, citra sekolah semakin meningkat, guru yang berkualitas, keterlibatan orang tua siswa, dukungan masyarakat serta hubungan yang menguntungkan dengan pelanggan eksternal sekolah. 


\section{DAFTAR PUSTAKA}

Abrori, M. (2015). Strategi Pemasaran Lembaga Pendidikan untuk Meningkatkan Jumlah Peserta Didik di PG/TK Samarinda. Syamil: Jurnal Pendidikan Agama Islam (Journal of Islamic Education), 3(2).

Alma, B. (2018), Manajemen Pemasaran dan Pemasaran Jasa, Edisi Revisi, Cet 13 Bandung: Alfabeta

Elytasari, S. (2017). Strategi Pemasaran Jasa Pendidikan untuk Meningkatkan Kepercayaan (Trust) Stakeholders di TK Amal Insani Depok Yogyakarta. Jurnal Warna, 1(1), 117-154.

Faizin, I. (2017). Strategi Pemasaran Jasa Pendidikan dalam Meningkatkan Nilai Jual Madrasah. Madaniyah, 7(2), 195108.

Haryanto, R., \& Rozza, S. (2012). Pengembangan Strategi Pemasaran Dan Manajemen Hubungan Masyarakat Dalam Meningkatkan Peminat Layanan Pendidika. Jakarta State Polytechnic.

Hasbullah, H., Juhji, J., \& Maksum, A. (2019). Strategi Belajar Mengajar Dalam Upaya Peningkatan Hasil Belajar Pendidikan Agama Islam. Edureligia; Jurnal Pendidikan Agama Islam, 3(1), 17-24.

Hidayat R. \&Wijaya, C. (2017) Ayat-Ayat Al-Quran Tentang Manajemen Pemasaran Pendidikan Islam. Medan: LPPPI.

Indrioko, E. (2015). Membangun Citra Publik dalam Lembaga Pendidikan Islam. Universum: Jurnal KeIslaman dan Kebudayaan, 9(2).

Juhji, J. (2020). Definisi, Perkembangan, Fungsi, dan Peran Humas Sekolah. In Manajemen humas sekolah. Widina Bhakti Persada Bandung.

Juhji, J., Khaeroni, K., Masto'ah, I., \& Habudin, H. (2019). Pendidikan Kecakapan Hidup dalam Pengembangan Kompetensi Lulusan Mahasiswa PGMI Memasuki MEA.
JIP (Jurnal Ilmiah PGMI), 5(1), 6073.

Khasanah, A. (2015). Pemasaran Jasa Pendidikan Sebagai Strategi Peningkatan Mutu di SD Alam Baturraden. El Tarbawi, 8(2), 161176.

Labaso, S. (2018). Penerapan Marketing Mix sebagai Strategi Pemasaran Jasa Pendidikan di MAN 1 Yogyakarta. MANAGERIA: Jurnal Manajemen Pendidikan Islam, 3(2), 289-311.

Machali, I.( 2015) The Handbook of Education Management. Yogyakarta: Magister Pendidikan Islam Universitas Islam Negeri Sunan Kalijaga.

Muhaimin, (2010). Manajemen Pendidikan Aplikasinya dalam Penyusunan Rencana Pengembangan Sekolah/Madrasah. Jakarta: Kencana.

Mukhtar, M. (2017). Pemasaran dan Upaya Dalam Mempengaruhi Harapan Stakeholder dalam Lembaga Pendidikan Islam. Tarbawi: Jurnal Pendidikan Islam, 14(2).

Munir, M. (2018). Manajemen Pemasaran Pendidikan Dalam Peningkatan Kuantitas Peserta Didik. Intizam, Jurnal Manajemen Pendidikan Islam, 1(2), 78-94.

Parid, M. (2016). Manajemen pemasaran pendidikan: Penelitian di Madrasah Aliyah Al-Ittihad Pangauban Bandung Barat (Doctoral dissertation, UIN Sunan Gunung Djati Bandung).

Rahman, S. (2015). Strategi Pemasaran Jasa Pendidikan Madrasah Dalam Meningkatkan Kompetensi Lulusan Di MAN 3 Kota Cirebon. Tesis. Yogyakarta, UIN Sunan Kalijaga.

Rantung, M., Sabijono, H., \& Tirayoh, V. Z. (2019). Penerapan Psak Nomor 45 tentang Pelaporan Keuangan Organisasi Nirlaba Pada SMK Negeri 1 Manado. Going Concern: Jurnal Riset Akuntansi, 14(3). 
Sarifudin, S., \& Maya, R. (2019). Implementasi Manajemen Pemasaran Jasa Pendidikan dalam Meningkatkan Kepuasan Pelanggan di Madrasah Aliyah Terpadu (MAT) Darul Fallah Bogor. Islamic Management: Jurnal Manajemen Pendidikan Islam, 2(02), 133-151.

Supardi, S. (2017). Peran Kepemimpinan dan Keterlibatan Group Decission Making dalam Perubahan Organisasi. Tarbawi: Jurnal Keilmuan Manajemen Pendidikan, 1(01), 37-48.

Supardi, S.
Tatang.(2015)

ManajemenPendidikanBerbasisSekol ah. Bandung: CV PustakaSetia,

Wahyudi, K. (2017). Manajemen Pemasaran Pendidikan. Kariman Jurnal Pendidikandan Keislaman. 5(1), 65-66.

Wahyuni, N. Y. (2018). Pencitraan: Upaya Membangun Public Opinion Bagi Lembaga Pendidikan Islam. $A l$ Tanzim: Jurnal Manajemen Pendidikan Islam, 2(1), 64-79.

Wijaya, D. (2016). Pemasaran Jasa

Pendidikan. Jakarta: Bumi Aksara (2017).StatistikPenelitianPendidikan . PT RajaGrafindoPersada 